\title{
PENGEMBANGAN LAMPU WARNA TERHADAP PERKEMBANGAN KOGNITIF ANAK KELOMPOK A DI TK PGRI 1 BANCARAN
}

\author{
Nurul Kholidiyah ${ }^{1}$ \\ Dwi Nurhayati Adhani ${ }^{2}$ \\ Siti Fadjryana Fitroh ${ }^{3}$ \\ ${ }^{1,2,3}$ Program Studi Pendidikan Guru Pendidikan Anak Usia Dini, Universitas Trunojoyo Madura \\ Email:nurulcahaya.nc28@gmail.com,adhaniuwi@gmail.com
}

Received (Bulan Januari 2020), Accepted (Bulan Februari 2020), Published (Bulan April 2020)

\begin{abstract}
The Development of Color Lights on The Cognitive Development of Group A Children in Kindergarten of PGRI 1 Bancaran. Researchers used a development model Borg \& Gall. Steps to be taken include the research and data collection, planning, early product development, initial test, revise the initial product, the main field testing and revision of the final product. Research and development is carried out through four stages of a trial that is testing subject matter experts, instructional media expert testing, field trials beginning, and major field trials. The subject of research and development that children in group A or 4-5 years in kindergarten PGRI 1 Bangcaran totaling 21 children. The data collection technique using a questionnaire (questionnaire subject matter experts, instructional media expert questionnaire, and the questionnaire responses of children) and documentation. The results showed that the values obtained from the color light matter experts for $86.11 \%$ with the title of "high", 76.67\% of instructional media expert with the title of "high", the initial field trials 83.9\%with the title of "high", and the main field trials $86.9 \%$ with the title of "high". Based on the results of research and development has been done can be concluded that the media color lights as stimulationability to recognize the concept of color in group A at TK PGRI 1 Bancaran fit for use.
\end{abstract}

Keywords: learning media, light color, ability to recognize the concept of color

\begin{abstract}
Abstrak: Pengembangan Lampu Warna Terhadap Perkembangan Kognitif Anak Kelompok A di TK PGRI 1 Bancaran. Peneliti menggunakan model pengembangan Borg \& Gall. Langkah yang ditempuh meliputi penelitian dan pengumpulan data, perencanaan, pengembangan produk awal, uji coba awal, revisi produk awal, uji coba lapangan utama dan revisi produk akhir. Penelitian dan pengembangan ini dilakukan melalui 4 tahapan uji coba yaitu uji coba ahli materi, uji coba ahli media pembelajaran, uji coba lapangan awal, dan uji coba lapangan utama. Subjek penelitian dan pengembangan yaitu anak kelompok A atau usia 4-5 tahun di TK PGRI 1 Bangcaran yang berjumlah 21 anak. Teknik pengumpulan data menggunakan angket (angket ahli materi, angket ahli media pembelajaran, dan angket respon anak) dan dokumentasi. Hasil penelitian menunjukkan bahwa nilai yang diperoleh lampu warna dari ahli materi sebesar $86,11 \%$ dengan predikat "tinggi", ahli media pembelajaran $76,67 \%$ dengan predikat "tinggi", uji coba lapangan awal 83,9 \% dengan predikat "tinggi", dan uji coba lapangan utama 86,9\% dengan predikat "tinggi". Berdasarkan hasil penelitian dan pengembangan yang telah dilakukan dapat disimpulkan bahwa media lampu warna sebagai stimulasi kemampuan mengenal konsep warna pada kelompok A di TK PGRI 1 Bancaran layak digunakan.
\end{abstract}

Kata kunci: media pembelajaran, lampu warna, kemampuan mengenal konsep warna. 
Jurnal PG-PAUD Trunojoyo : Jurnal Pendidikan dan Pembelajaran Anak Usia Dini, Volume 7, Nomor 1, April 2020, hal 47-51, ISSN : 2528-3553 (online), ISSN: 2407-4454 (print)

\section{PENDAHULUAN}

Anak usia dini menurut NAEYC (National Association for The Educational of Young Children) dalam Ambara mengatakan bahwa batasan umur untuk anak usia dini adalah dari usia nol sampai usia 8 tahun, yang didalamnya mencakup program pendidikan di taman penitipan anak, penitipan anak pada keluarga, pendidikan prasekolah baik swasta maupun negeri, TK, dan SD (Ambara, 2014). Berdasarkan penjelasan diatas, anak usia dini merupakan anak yang sedang berada pada rentang usia 0-8 tahun yang juga disebut Golden Age (Masa Keemasan), yaitu masa dimana anak sudah mulai peka terhadap lingkungan sekitarnya dan dapat menerima berbagai rangsangan.

Masa emas khusus usia 4-5 tahun anak mengalami masa peka, dimana anak mulai merasa sensitif untuk menerima berbagai stimulus. Menurut Montessori perkembangan anak terdapat masa peka, suatu masa yang ditandai dengan begitu tertariknya anak terhadap suatu objek atau karakteristik tertentu serta cenderung mengabaikan objek yang lainnya. Masa peka pada masing-masing anak berbeda, seiring dengan laju pertumbuhan dan perkembangan anak secara individual (Habibi, 2018).

Anak usia dini terdapat 6 aspek dalam pertumbuhan dan perkembangan secara bertahap. Menurut Masnipal "terdapat enam aspek dasar dalam perkembangan anak usia dini yaitu fisik motorik, kognitif, atau intelektual, bahasa, emosi, dan sosial. Perkembangan moral, agama, seni dan kreativitas bukan bagian terpisah dari lima aspek tetapi termasuk didalamnya (Masnipal, 2013). Perkembangan kognitif merupakan suatu proses perkembangan berfikir atau kecerdasan, dimana anak mampu mempelajari konsep baru dan keterampilan untuk memahami yang terjadi di lingkungan sekitarnya.

Tahapan perkembangan kognitif anak sesuai dengan usia 4-5 tahun dijelaskan dalam Peraturan Menteri dan Kebudayaan Republik Indonesia Nomor 137 Tahun 2013 tentang Standar Nasional Pendidikan Anak Usia Dini bahwa: "Mengklasifikasikan benda berdasarkan fungsi, bentuk atau warna atau ukuran. Mengenal gejala sebab-akibat yang terkait dengan dirinya. Mengklasifikasikan benda ke dalam kelompok yang sama atau kelompok yang sejenis atau kelompok yng berpasangan dengan 2 variasi. Mengenal pola (misal, AB-AB dan $\mathrm{ABC}-\mathrm{ABC}$ ) dan mengulanginya. Mengurutkan benda berdasarkan 5 seriasi ukuran atau warna" Pernyataan diatas dapat dicermati bahwa perkembangan kognitif merupakan aspek yang sangat penting untuk dikembangkan guna mengasah kemampuan anak dalam mengenal objek salah satunya warna.

Menurut Syaiful Bahri Djamarah dan Aswan Zain menyatakan bahwa "Media merupakan suatu alat bantu apa saja yang dapat dijadikan sebagai penyalur pesan guna mencapai tujuan pengajaran" (Djamarah dan Zain, 2010). Berdasarkan pemaparan diatas, media merupakan suatu alat bantu yang dapat menyalurkan pesan sehingga dapat merangsang pikiran, perasaan, perhatian dan minat anak guna mencapai tujuan pembelajaran. Banyak sekali media pembelajaran yang salah satunya yaitu media buku cerita bergambar.

Kemampuan mengenal warna merupakan bagian dari kemampuan kognitif, dimana kemampuan mengenal warna tersebut hal yang sangat penting bagi perkembangan otak anak karena pengenalan warna dapat merangsang indra penglihatan anak. selain merangsang indra penglihatan anak mengenal warna juga dapat meningkatkan kreativitas anak dan daya pikir dalam kemampuan mengingat. Menurut Permendiknas Nomor 58 Tahun 2009 mengatakan bahwa pengenalan warna untuk anak usia 3-4 tahun yaitu berada pada mengenal 5-7 macam warna. Adapun pendapat lain mengatakan bahwa kemampuan mengenal warna sangat diperlukan oleh seorang anak sebelum memasuki usia pra sekolah, sebab kemampuan mengenal warna nantinya akan berhubungan dengan kemampuan untuk berfikir secara logis dan sistematis. Maka dari itu pengenalan warna sangat diperlukan pada anak usia 3-4 tahun untuk menumbuhkan kreatifitas anak lebih lanjut.

Berdasarkan pengamatan awal yang dilakukan pada tanggal 7 Februari 2019 di TK PGRI 1 Bancaran dan tanggal 6 September 2019 dari hasil pengamatan lanjutan terdapat permasalahan yang sama yaitu, saat kegiatan 
pembelajaran di kelompok A terdapat permasalahan perkembangan kognitif. Terlihat masih banyak anak yang kurang mampu membedakan warna yang tidak sesuai petunjuk guru, khususnya pada anak kelompok A yang berjumlah 21 anak, terdapat 10 anak yang terlihat kurang mampu mengenal warna. Misal guru memberikan petunjuk warna hijau anak menjawab warna biru. Selain itu, media pembelajaran konsep warna, guru memberikan stimulasi terhadap anak berupa tebak warna, dengan media yang digunakan sangat sederhana berupa kertas origami dan krayon. Diperoleh hasil bahwa anak belum mampu menunjukkan, menyebutkan dan mengklasifikasikan warna dengan benar. Hal tersebut disebabkan minimnya pengetahuan anak terkait warna dan keterbatasan media dalam mengenalkan warna.

Saat peneliti melakukan observasi sering kali menjumpai guru menggunakan kertas origami dan krayon sebagai media untuk menstimulasi anak kelompok A di TK PGRI 1 Bancaran. Dimana sebelum kertas origami dilipat dan dibentuk sesuai keinginan, guru akan melontarkan pertanyaan (tebak warna) sesuai warna kertas origami tersebut, sedangkan kertas origami hanya terdiri dari beberapa macam warna dan untuk krayon dimana ketika kegiatan mewarnai guru akan mengarahkan anak untuk memberikan warna sesuai dengan gambar yang akan diwarnai (misal; daun warna hijau).

Adanya beberapa media yang berada di TK PGRI 1 memberikan inspirasi bagi peneliti untuk mengembangkan media pembelajaran guna menarik perhatian anak dalam belajar, terutama untuk mengembangkan kemampuan mengenal konsep warna. Peneliti memilih media lampu untuk dikembangkan karena media lampu diharapkan dapat menjadi media pembelajaran yang menarik bahwa pembelajaran pengenalan warna bisa digunakan melalui cahaya lampu menyala yang dibantu adanya aliran arus listrik atau batrai. Tersedianya tombol dengan beraneka macam warna, yang nantinya akan memancarkan warna lampu sesuai dengan warna tombol yang ditekan. Hal ini akan lebih menarik dihadapan anak, serta menjadikan anak lebih mengekspor rasa ingin tahu mereka akan warna. Manfaat mengenal warna diantaranya, membantu mengenal warna perbedaan warna, warna merupakan media terapi, dan melatih kemampuan koordinasi. Permasalahan diatas menjadikan peneliti tertarik untuk melakukan penelitian tentang "Pengembangan lampu warna terhadap perkembangan kognitif anak kelompok A di TK PGRI 01 Bancaran.”

\section{METODE}

Metode penelitian ini menggunakan metode penelitian dan pengembangan atau yang biasa disebut Research and Development (R\&D). Model penelitian yang digunakan dalam pengembangan lampu warna yaitu model pengembangan Borg and Gall. Pada model Borg and Gall terdiri dari 10 langkah penelitian pengembangan, yaitu: Penelitian pendahuluan dan pengumpulan informasi (Research and Information Collecting), perencanaan (Planning), pengembangan produk awal (Develop Preliminary Form a Product), uji coba terbatas (Preliminary Field Testing), revisi produk tahap awal (Main Product Revision), uji coba lapangan utama (Main Field Testing), revisi produk (Operational Product Revision), uji coba lapangan operasional (Operational Field Testin), dan revisi produk tahap akhir (Final Product Revision), implementasi (Dissemination and Implementation) (Sugiyono, 2017: 35-36). Penelitian dengan model pengembangan ini hanya melakukan 7 langkah pengembangan karena hanya menguji pada satu lembaga.

Subjek yang digunakan dalam penelitian adalah validasi ahli (ahli materi dan ahli media pembelajaran) dan anak usia 4-5 tahun atau kelompok A di TK PGRI 1 Bancaran. Pemilihan validasi ahli sesuai dengan bidang yang terkait dengan penelitian. Penelitian ini menggunakan jenis data kuantitatif dan data kualitatif. Hal ini digunakan untuk mendapatkan penilaian dari hasil angket dan saran perbaikan yang diberikan oleh subjek uji data.

Instrumen pengumpulan data yang digunakan dalam penelitian ini yaitu angket dan dokumentasi. Angket digunakan untuk pengambilan penilaian dari validasi ahli dan respon anak terhadap lampu warna yang sudah dikembangkan, sedangkan dokumentasi 
Jurnal PG-PAUD Trunojoyo : Jurnal Pendidikan dan Pembelajaran Anak Usia Dini, Volume 7, Nomor 1, April 2020, hal 47-51, ISSN : 2528-3553 (online), ISSN: 2407-4454 (print)

digunakan untuk pengambilan bukti foto dalam pengambilan data.

Teknik analisis data dalam penelitian yaitu dengan menggunakan analisis kuantitatif dan deskripsi kualitatif. Data penelitian pengembangan yang dianalisis menggunakan analisis kuantitatif adalah analisis kelayakan yang mana validasi yang dilakukan untuk mengetahui kelayakan lampu warna yaitu dengan cara melakukan analisis dari validasi ahli media dan ahli materi atau angket yang terkumpul. Data diperoleh merupakan data kuantitatif, dari hasil yang diperoleh dapat dihitung prosentase tiap-tiap butir pernyataan dengan rumus menurut Komang I (Ramansyah, 2018) sebagai berikut.

$$
\text { prosentase jawaban }=\frac{F}{N} \times 100 \%
$$

Pemberian makna dan pegambilan keputusan tentang kualitas produk media pembelajaran ini akan menggunakan konversi tingkat pencapaian skala 5 sebagai berikut.

\section{Tabel 1 Tingkat Pencapaian Skala}

\begin{tabular}{|c|c|c|}
\hline $\begin{array}{c}\text { Tingkat } \\
\text { Pencapaian }\end{array}$ & Predikat & Keterangan \\
\hline $90 \%-100 \%$ & Sangat Tinggi & $\begin{array}{c}\text { Sangat layak, } \\
\text { tidak perlu } \\
\text { direvisi }\end{array}$ \\
\hline $75 \%-89 \%$ & Tinggi & $\begin{array}{c}\text { Layak, tidak perlu } \\
\text { direvisi }\end{array}$ \\
\hline $65 \%-74 \%$ & Cukup Tinggi & $\begin{array}{c}\text { Kurang layak, } \\
\text { perlu direvisi }\end{array}$ \\
\hline $55 \%-64 \%$ & Kurang Tinggi & $\begin{array}{c}\text { Tidak layak, perlu } \\
\text { direvisi }\end{array}$ \\
\hline $5 \%-54 \%$ & Sangat Kurang & $\begin{array}{c}\text { Sangat tidak } \\
\text { layak, perlu } \\
\text { direvisi }\end{array}$ \\
\hline
\end{tabular}

Analisis kualitatif digunakan untuk mengolah data dari hasil data para ahli dan data uji coba pada anak kelompok A TK PGRI 1 Bancaran. Teknik analisis kualitatif dilakukan dengan mengelompokkan informasi berupa tanggapan, kritik atau saran perbaikan yang terdapat pada angket yang sudah terisi angka penilaian. Informasi tersebut digunakan untuk perbaikan produk pengembangan media origami kain. Hasil analisis kualitatif ini untuk mengumpulkan informasi saran perbaikan dari subjek uji coba.

\section{HASIL DAN PEMBAHASAN}

Hasil penelitian pengembangan lampu warna terhadap perkembangan kognitif kelompok A TK PGRI 1 Bancaran menjelaskan tentang kelayakan lampu warna sebagai alat bantu pembelajaran. Penilaian dilihat dari hasil bukti pada lembar angket yang diberikan kepada subjek uji coba. Berikut hasil penilaian dari uji coba ahli (materi dan media pembelajaran) serta uji coba lapangan (lapangan awal dan utama).

Hasil presentase yang diperoleh dari angket ahli materi terhadap perkembangan media lampu warna memperoleh hasil presentase sebesar $86,11 \%$. Dilihat dari hasil presentase ahli materi yang diperoleh disesuaikan dengan tabel 3.4 (Tabel Tingkat Pencapaian Penilaian), dimana pengembangan media lampu warna berada pada kategori "tinggi" dengan keterangan "layak, tidak perlu direvisi".

Hasil presentase yang diperoleh dari angket ahli media Pembelajaran terhadap perkembangan lampu warna memperoleh hasil presentase sebesar $76,67 \%$. Dilihat dari hasil presentase ahli materi yang diperoleh disesuaikan dengan tabel 3.4 (Tabel Tingkat Pencapaian Penilaian), dimana pengembangan lampu warna berada pada kategori "tinggi" dengan keterangan "layak, tidak perlu direvisi".

Hasil data presentase yang didapatkan dari uji coba lapangan awal terhadap lampu warna yang terdiri dari 6 anak memperoleh hasil prosentasi sebesar $83,9 \%$. Hasil yang diperoleh dapat disesuaikan dengan kategori pada tabel 3.4 (Tabel Pencapaian Penilaian), yang mengatakan bahwa hasil angket respon anak terhadap lampu warna terdapat dalam kategori "tinggi" dimana keterangan yang dijelaskan dalam pencapaian penilaian merupakan layak, tidak perlu direvisi sehingga produk lampu warna sudah dapat digunakan tanpa adanya revisi.

Hasil presentase yang diperoleh dari uji coba lapangan utama yang terdiri dari 15 anak terhadap pengembangan media lampu warna presentase sebesar 86,9\%. Hasil tersebut disesuaikan dengan tabel 3.4 (Tabel Tingkat Pencapaian Penilaian), dimana hasil angket responden terhadap media lampu warna berada pada predikat "tinggi". Hal ini dapat disimpulkan bahwa mendapatkan respon yang 
sangat baik pada anak. sehingga produk media lampu warna dapat dilanjutkan tidak perlu adanya revisi dikarenakan tidak adanya kritik dan saran yang dapat dijadikan pertimbangan peneliti untuk direvisi.

\section{SIMPULAN}

Berdasarkan hasil penelitian dan pengembangan, dapat disimpulkan sebagai berikut:

1. Perkembangan Lampu warna dihasilkan dengan menggunakan tujuh langkah pengembangan Borg \& Gall dengan serangkaian uji coba serta uji validasi ahli materi dan ahli media pembelajaran. Lampu warna yang dikembangkan digunakan sebagai stimulasi untuk meningkatkan kognitif anak pada kelompok A di TK PGRI 1 Bancaran.

2. Kelayakan lampu warna sebagai stimulasi perkembagan kognitif anak pada kelompok A di TK PGRI 1 Bancaran dibuktikan melalui hasil dari penilaian produk yang telah dilakukan oleh ahli materi dan ahli media pembelajaran,. Hasil penilaian dari ahl

3. materi sebesar $86,11 \%$ dengan predikat "layak" sedangkan hasil penilaian dari ahli media pembelajaran sebesar $79,67 \%$ dengan predikat "layak".

4. Respon yang diberikan oleh anak didik terhadap media lampu warna sangat baik dan antusias dalam penggunaan dalam uji coba lapangan. Hal ini dibuktikan dengan hasil penilaian angket responden hasil uji coba lapangan awal sebesar $83,9 \%$ dengan predikat "tinggi". Sedangkan penilaian uji coba produk lapangan utama sebesar $86,9 \%$ dengan predikat "tinggi".

Adapun saran dari penelitian ini adalah sebagai berikut.
1. Bagi peneliti atau pengembang selanjutnya, diharapkan dapat mengembangkan media buku cerita dengan seri yang berbeda.

2. Bagi peneliti atau pengembang selanjutnya, diharapkan media buku cerita bergambar dapat diimplementasikan sebagai media pembelajaran untuk meningkatkan berbagai aspek perkembangan anak usia 5-6 tahun.

3. Bagi pengajar atau pendidik dapat menjadikan media buku cerita bergambar sebagai alternatif media pembelajaran.

\section{DAFTAR PUSTAKA}

Ambara, Didith Pramunditya, dkk, Asesmen Anak Usia Dini. (2014). Yogyakarta: Graha Ilmu

Djamarah, Syaiful Bahri dan Aswan Zain. (2010). Strategi Belajar Mengajar. Jakarta: Rineka Cipta.

Habibi, M. (2018). Analisis Kebutuhan Anak Usia Dini Buku Ajar S1 PAUD. Yogyakarta : Deepublish.

Masnipal. (2013). Siap Menjadi Guru dan Pengelola PUAD Profesional. Jakarta: PT Gramedia.

M. Fadlillah. (2012). Desain Pembelajaran PAUD. Yogyakarta: AR-RUZ Media

Nurgiyantoro, B. (2005). Sastra Anak PengantarPemahaman Dunia Anak. Yogyakarta: Gadjah Mada University.

Peraturan Menteri Pendidikan Nasional Nomor 58 Tahun 2009 Tentang Standar Pendidikan Anak Usia Dini .

Ramansyah, W. (2018). Model-Model Pengembangan Media Pembelajaran. Bangkalan: UTM Press

Sugiyono. (2017). Metode Penelitian dan Pengembangan. Bandung: Alfabeta.

Yuliani, Nurani Sujiono. (2012). Konsep Dasar Pendidikan Anak Usia Dini. Jakarta: PT Ind 